\title{
Epithelioid leiomyoma of the eyelid. A case report
}

\section{Leiomioma epitelioide en el párpado. Reporte de un caso}

\author{
Albanydia Montiel-Arista ${ }^{1 *}$, Alfredo Medina-Zarco², Fernando E. de la Torre-Rendón ${ }^{3}$, \\ Claudia Herrera-Dorantes ${ }^{3}$ and Diana I. González-Hinojosa² \\ 1Ophthalmology Department; ${ }^{2}$ Orbit, Eyelid and Lacrimal Tract Service; ${ }^{3}$ Pathology Service. Hospital Regional Lic. Adolfo López-Mateos, Instituto \\ de Seguridad y Servicios Sociales de los Trabajadores (ISSSTE), Mexico City, Mexico
}

\begin{abstract}
We present the case of a rare histological eyelid tumor in an 18-year-old female with a painful erythematous nodule in her upper right eyelid for which conservative treatment was initiated; however, she suffered a relapse and then a biopsy was performed. Histopathology examination revealed an epithelioid leiomyoma. Rare tumors may develop in the eyelids, mainly of the stromal type. In cases of eyelid tumors, biopsy and histopathological examination are mandatory to confirm clinical diagnosis and treatment.
\end{abstract}

Key words: Pseudotumor. Eyelid tumor. Epithelioid leiomyoma. Spindle cells. Muscle-specific actin. Excisional biopsy.

\section{Resumen}

Se describe el caso clínico sobre un tumor de estirpe histológica poco frecuente en cuanto a su localización, en un paciente de sexo femenino de 18 años de edad, quien inició con un nódulo eritematoso y doloroso en el párpado superior derecho, que se trató de forma conservadora, con buen resultado terapéutico; sin embargo, posterior a 1 año de evolución recidivó en el mismo sitio, por lo que se realizó biopsia. El reporte histopatológico fue un leiomioma epitelioide. Los párpados pueden ser el sitio de desarrollo de tumores poco comunes, en la mayoría de los casos estromales. La conducta terapéutica ante un tumor palpebral exige biopsia y análisis histopatológico para establecer el diagnóstico y tratamiento correctos.

Palabras clave: Pseudotumor.Tumor palpebral. Leiomioma epitelioide. Células fusiformes. Actina específica a músculo. Biopsia excisional.

\section{Introduction}

Tumoral and pseudo tumoral eyelid lesions can have the same clinical appearance, so the cornerstone for diagnosis and prognosis is their histopathological nature. Uniform color, limited growth, regular borders, preservation of the eyelid margin and absence of induration and/ or ulceration, are characteristic of pseudo tumoral lesions, and the most common examples are benign nodules and cysts, such as hordeolum, chalazion, epidermal inclusion cyst, epidermoid cyst, dermoid cyst, sebaceous cyst, cysts of Zeiss and Moll, eccrine hidrocystoma, miliary acne, blackheads, etc. ${ }^{1-3}$ (Table 1). Uncommon tumors, mainly of the stromal type, may appear in the eyelids. Smooth muscle tumors of the eyelids, such as leiomyomas and leiomyosarcomas, are very rare $^{4}$. Hui, et al., from the Bascom Palmer Eye Institute,

Correspondence:

*Albanydia Montiel-Arista

Av. Universidad, 1321

Col. Florida, Del. Álvaro Obregón

Date of reception: 26-11-2018

Date of acceptance: 09-09-2019

E-mail: dra.albanydia.uaeh@gmail.com (http://creativecommons.org/licenses/by-nc-nd/4.0/).

Available online: 09-11-2020 Rev Mex Oftalmol (Eng). 2020;94(6):253-256 www.rmo.com.mx

ublished by Permanyer. This is an open access article under the CC BY-NC-ND license 
Table 1. Tumoral and pseudo-tumoral eyelid lesions

\begin{tabular}{|c|c|}
\hline Benign lesions & Malignant lesions \\
\hline $\begin{array}{l}\text { Epidermoid papilloma } \\
\text { Basal cell papilloma } \\
\text { Inverted follicular keratosis } \\
\text { Actinic keratosis } \\
\text { Common wart } \\
\text { Tricholemoma }\end{array}$ & $\begin{array}{l}\text { Basal cell carcinoma (most common). } \\
\text { Squamous cell carcinoma } \\
\text { Sebaceous carcinoma }\end{array}$ \\
\hline $\begin{array}{l}\text { Main erythematous nodular lesions with an inflammatory appearance } \\
\text { Chalazion } \\
\text { Capillary hemangioma } \\
\text { Pseudocarcinomatous hyperplasia } \\
\text { Pyogenic granuloma } \\
\text { Epithelioid or spindle cell nevus } \\
\text { Pleomorphic adenoma } \\
\text { Exocrine acrospiroma } \\
\text { Pilomatrixoma } \\
\text { Glomus tumor } \\
\text { Juvenile xanthogranuloma } \\
\text { Benign intravascular endothelial hyperplasia }\end{array}$ & $\begin{array}{l}\text { Basal cell carcinoma } \\
\text { Merkel's tumor } \\
\text { Nodular malignant melanoma } \\
\text { Mucinous adenocarcinoma } \\
\text { Angiosarcoma } \\
\text { Kaposi's sarcoma }\end{array}$ \\
\hline $\begin{array}{l}\text { Main nodular lesions without color changes of the integuments or pigmented } \\
\text { Chalazion } \\
\text { Granular cell tumor } \\
\text { Dermal nevus } \\
\text { Epithelioid or spindle cell nevus } \\
\text { Syringoma } \\
\text { Molluscum contagiosum } \\
\text { Pseudo-rheumatoid nodule } \\
\text { Sarcoidosis nodule }\end{array}$ & $\begin{array}{l}\text { Basal cell carcinoma } \\
\text { Sebaceous carcinoma } \\
\text { Nodular malignant melanoma } \\
\text { Mucinous adenoma }\end{array}$ \\
\hline $\begin{array}{l}\text { Major ulcerated nodular lesions or with a keratin crater } \\
\text { Keratoacanthoma } \\
\text { Hordeolum-chalazion } \\
\text { Exocrine acrospiroma } \\
\text { Trichoepithelioma } \\
\text { Tricholemoma } \\
\text { Nodular fasciitis }\end{array}$ & $\begin{array}{l}\text { Basal cell carcinoma } \\
\text { Squamous cell carcinoma }\end{array}$ \\
\hline
\end{tabular}

published in 2010 the first case report of a primary leiomyoma in the left lower eyelid, in a 10-year-old boy, manifested as a recurrent painful nodule ${ }^{5}$.

Leiomyomas are slow-growing lesions that originate from the smooth muscle. Its location has been described intraorbital in 25 cases; histological characteristics and the absence of recurrence after complete resection support their benign behavior6. On the other hand, Lin $\mathrm{J}$, et $\mathrm{al}^{7}$ reported eight cases of angioleiomyoma, of which six were intraconal and two were located in the eyelid, and were more frequent in males. The palpebral conjunctiva is another uncommon site where leiomyoma has been reported ${ }^{8}$.

\section{Case presentation}

This is an 18-year-old female, resident of Mexico City, with no relevant personal history. Her condition began with the appearance of an erythematous and painful nodule in the inner third of the upper right eyelid margin, which was treated conservatively with antibiotics and an anti-inflammatory ophthalmic ointment, and progressed favorably to resolution. However, after 1 year, the tumor recurred in the same location, involving the lacrimal punctum (Figs. 1 and 2). An incisional biopsy of the nodule did not help to obtain conclusive results, so an excisional biopsy was performed for histopathology evaluation (Figs. 3 and 4) along with repair of the lacrimal tract and the upper eyelid (Fig. 5).

The microscopic study reported a non-encapsulated stromal tumor of the eyelid skin. It contained poorly cohesive spindle and epithelioid cells, mixed with collagen. There was no atypia, and mitotic activity was sporadic. Immunohistochemistry was performed for the markers listed in Table 2. The only useful positivity was for smooth muscle actin, and therefore, it was ultimately classified 


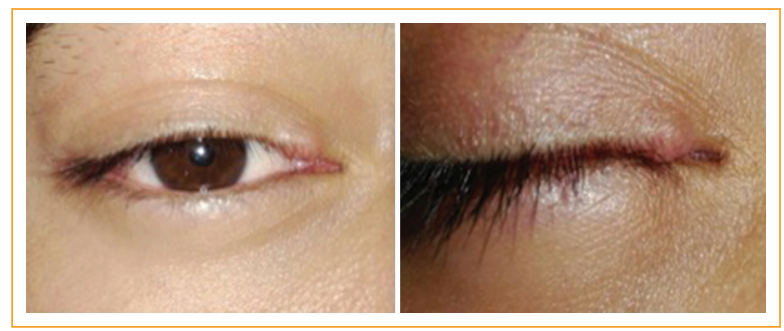

Figure 1. External clinical appearance of the tumor in the inner third of the right upper eyelid.

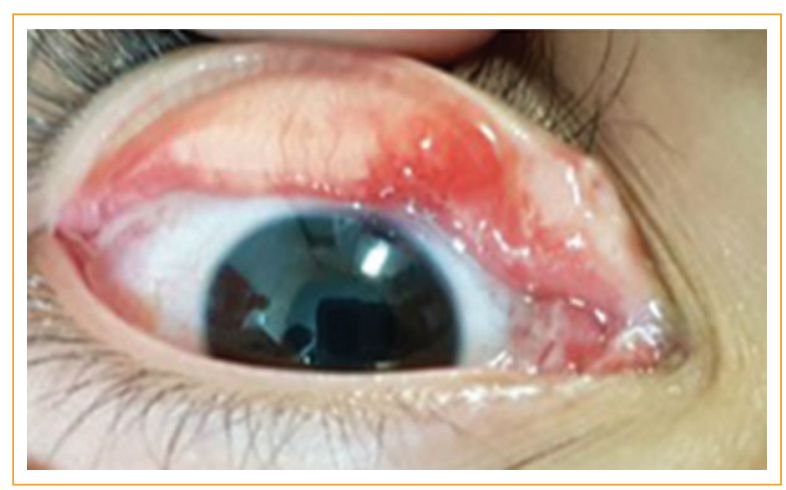

Figure 2. Clinical appearance of the tumor in the inner third of the right upper eyelid.

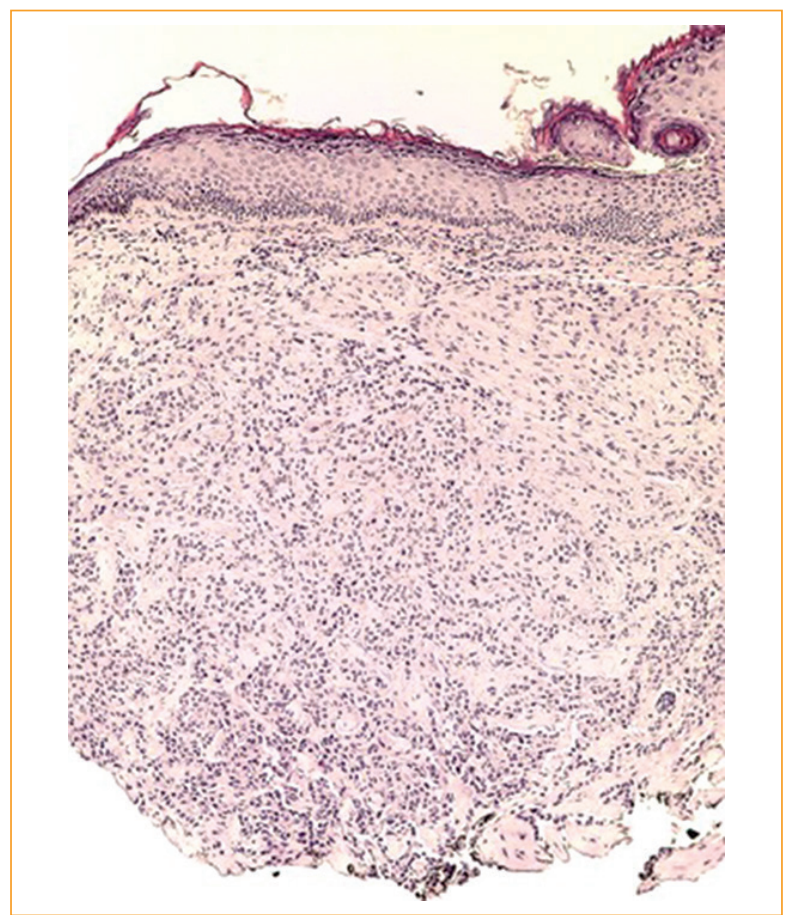

Figure 3. Eyelid skin showing cell proliferation at the level of the dermal stroma with a corded pattern, poorly delimited, that dissects the collagen fibers (H\&E 100x).

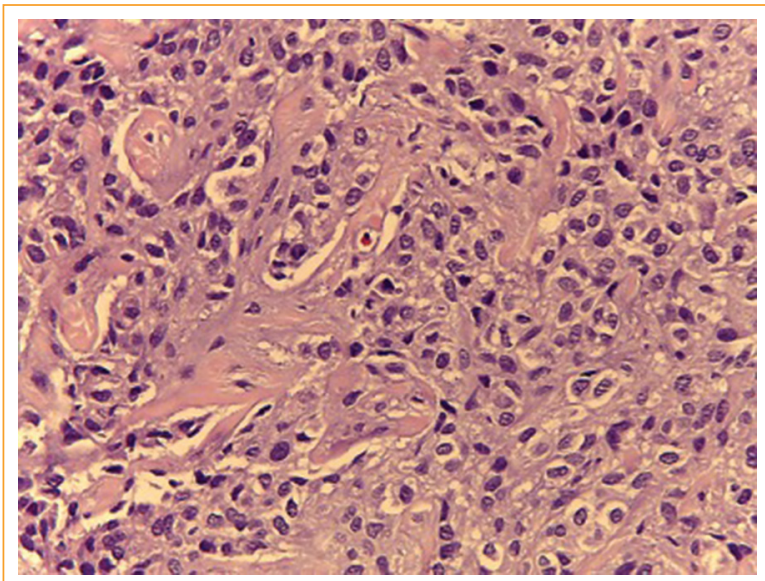

Figure 4. Proliferation of round epithelioid cells with abundant pale cytoplasm, showing a slight variation in shape and size (H\&E 400x).

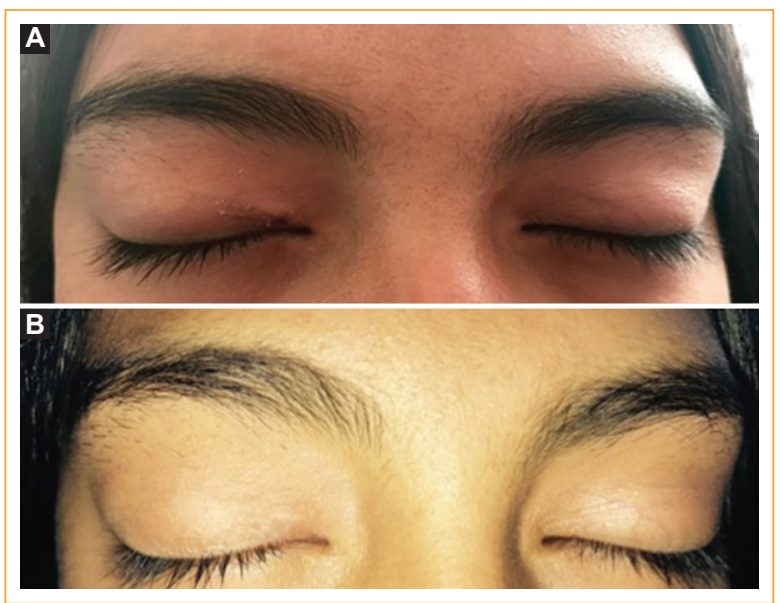

Figure 5. A: Clinical appearance in the first postoperative weeks B: Clinical appearance 1 month after surgery.

as an epithelioid leiomyoma with free surgical margins (Fig. 6). Negative markers ruled out the possibilities of histiocytic or Langerhans cell neoplasm, neuroendocrine, nerve sheath, epithelial or melanocytic neoplasms.

\section{Discussion}

The first condition to treat any eyelid tumor is to establish a diagnosis that must be corroborated by histopathology. Leiomyomas are neoplasms that originate from the smooth muscle. At the systemic level, they are observed mainly in the uterus. Intraocular and orbital location is infrequent. Intraconal location has been reported in $46.2 \%$, 
Table 2. Immunohistochemistry tests and results

\begin{tabular}{|l|l|}
\hline Marker & Result \\
\hline CD163 & Negative \\
\hline CD68 & Negative \\
\hline Calponin & Negative \\
\hline Desmin & Negative \\
\hline Myoglobin & Negative \\
\hline Chromogranin & Negative \\
\hline CD34 & Negative \\
\hline Melanoma cocktail & Negative \\
\hline Pankeratin & Negative \\
\hline S100 protein & Negative \\
\hline Smooth muscle-specific actin & Positive \\
\hline Ki67 & Negative \\
\hline
\end{tabular}

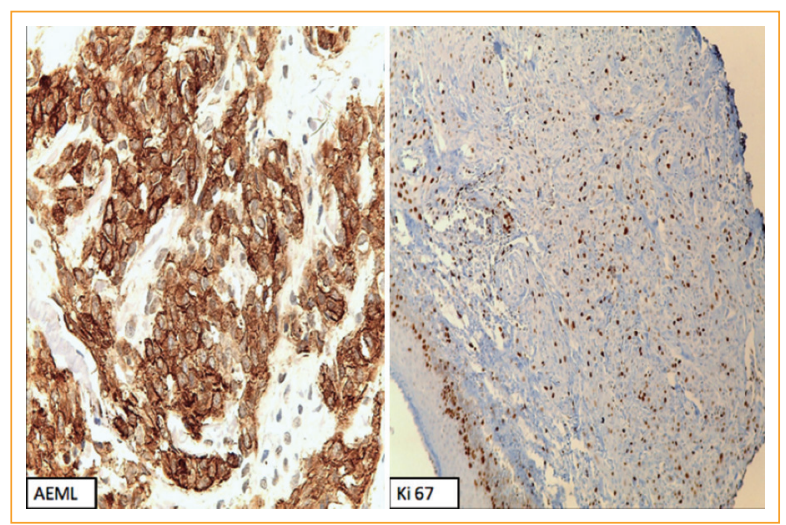

Figure 6. Immunohistochemistry revealed positivity for smooth muscle-specific actin throughout the lesion, with a Ki67 proliferation index of $20 \%$.

extraconal in $11.5 \%$ and intra-extraconal in $7.7 \%$ of the cases $^{5}$. They can be found in the anterior compartment in $30.8 \%$ or be diffuse in $3.8 \%$ of the cases. The origin of these tumors is uncertain due to the scarcity of smooth muscle in the orbit, located only in the capsulo-palpebralis muscle of Hessar and Müller or in blood vessel walls ${ }^{9,10}$.

Histologically, leiomyomas show a population of spindle cells with a fascicular distribution pattern, eosinophilic cytoplasm, perinuclear retraction, and nuclei with blunt edges and no mitotic activity. By immunohistochemistry, leiomyomas are positive for smooth muscle actin, desmin, and vimentin ${ }^{11}$. Leiomyomas show a spectrum that varies from a low vascular component to hemangioleiomyomas, where there is profuse vascularization with vessels of variable caliber and a thick muscular layer ${ }^{12}$. The differential diagnosis includes benign spindle cell tumors, such as neurofibroma, fibrous histiocytoma, and neurinoma. Leiomyosarcoma is the malignant form of a leiomyoma and shows a high degree of mitosis, cellular atypia and necrosis ${ }^{13}$. Surgical removal of the lesion and biopsy is the treatment of choice.

\section{Conclusions}

Tumoral and pseudo tumoral eyelid lesions are difficult to differentiate clinically, so the approach and treatment should always be accompanied by excisional biopsy and histopathology evaluation.

\section{Conflicts of interest}

The authors declare no conflicts of interest.

\section{Ethical disclosures}

Protection of human and animal subjects. The authors declare that no experiments were performed on humans or animals for this study.

Confidentiality of data. The authors declare that they have followed the protocols of their work center on the publication of patient data.

Right to privacy and informed consent. The authors have obtained the written informed consent of the patients or subjects mentioned in the article. The corresponding author is in possession of this document.

\section{References}

1. Kanski JJ, Bowling B. Oftalmología clínica. 7.르 ed. Elsevier; 2012. p. 4-5

2. Curutcher Mesner L, Peñate Santana H, Romero Báez S, Rutllán Civit J, Medina Rivero F. Tumores palpebrales. Aspectos clínicos y su correlación con la histopatología de una series de 305 casos. Arch Soc Canar Oftal. 2012;23:40-5

3. Audelan A. Tumor Palpebral. En:Enciclopedia práctica de medicina. Cap. V. 6- 0170/12.426.

4. Pe'er J. Pathoogy of eyelid tumors Indian. J Ophtalmol. 2016;64(3):177-90.

5. Hui JI, Buchser NM, Dubovy SR. Primary eyelid leiomyoma. Ophtalmic Plast Reconstr Surg. 2011;27(4):e102-3

6. González-Martínez E, Robla Costales J, Fernández Fernández J, Viñuela Lobo J, Santamarta D, Lomas García J, et al. Leiomioma intraorbitario. Caso clínico y revisión de la literatura. Neurocirugia.2014;25(1):33-7.

7. Lin J, et al, Zhonghua Yan Ke Za Zhi, Clinicopathologic characteristics of angioleiomyoma of the eyelids and orbit. Zhonghua Yan Ke Za Zhi. 2015; 51(8):586-91.

8. Barsegian A, Ahmad A, Shinder R. Leiomyoma of the Palpebral Conjuntiva. Ophtalmology. 2017;124(1):65.

9. Jakobiec FA, Jones IS, Tanenbaum M. Leiomyoma. An unusual tumour of the orbit. Br J Ophtalmol. 1973;57:825-31

10. Yan J, Zhou S, Li Y. Bening orbital tumors with bone destruction in children. PLoS One. 2012;7:e32111.

11. Gunduz K, Gunalp I, Erden E, Erekul S. Orbital leiomyoma: Report of a case and review of the literatura. Surv Ophtalmol. 2004;49:237-42.

12. Jakobiec FA, Jones IS, Tanenbaum M. Leiomyoma. An unusual tuour of the orbit. Br J Ophtalmol. 1973;57:825-31.

13. Wiechens B, Werner JA, Luttges J, Rudert H, Rochels R. Primary orbital leiomyoma and leiomyosarcoma. Ophthalmologica. 1999;213:159-64. 